\title{
Danger in deep water or just ripples in the pool: has the Pool judgment changed the law on expert evidence? ${ }^{\dagger}$
}

\author{
Keith Rix, Anthony Haycroft \& Nigel Eastman
}

\begin{abstract}
SUMMARY
The professional regulatory cases of the psychiatrist Dr Richard Pool and the neuropathologist Dr Waney Squier have given rise to concerns among expert psychiatric witnesses, and indeed medical experts in general. Here we restate the law on expert evidence with particular reference to the judgment of the Supreme Court in the case of Kennedy v Cordia. We emphasise that Pool does not change the law regarding 'what is expertise'; in particular, the case does not establish restrictive, status-based tests governing the admissibility of expert evidence such as according to whether an expert psychiatric witness has undergone higher training, is on the specialist register as a specialist in a particular field or is a consultant. Rather, expertise continues to be legally defined in terms of a combination of qualification, knowledge and experience. Crucially, the test of medical expertise in legal proceedings is a legal test and not one determined within a medical paradigm.
\end{abstract}

\section{LEARNING OBJECTIVES}

- Understand the law defining admissible expert evidence, in particular the distinction between 'admissibility' of evidence as 'expert' and the evidential 'weight' that courts may accord to admissible expert evidence

- Understand the issues that arose from the cases of Dr Pool and Dr Squier, and why they caused (unnecessary) medical concern

- Understand the factual relevance to being an expert witness of having undergone higher training, being on the specialist register as a specialist in a particular field, and being a consultant

\section{DECLARATION OF INTEREST}

None

At a preliminary hearing of the Health Professions Council (HPC) ${ }^{\text {a }}$ concerning the fitness to practise of a paramedic diagnosed with a personality disorder, the evidence of a psychiatrist, Dr Richard Pool, was rejected because he 'was not an expert in the field of general adult psychiatry'. Following complaint to the General Medical Council (GMC), a fitness to practise panel (FPP) of the Medical Practitioners Tribunal Service (MPTS) determined that Dr Pool had acted outside his area of expertise and therefore found his fitness to practise to be impaired. He exercised his right to appeal and the Administrative Court (Pool V General Medical Council [2014]) upheld the MPTS decision on impairment, but substituted a reduced sanction that Dr Pool should not provide expert evidence in fitness to practise cases for 3 months. This case raised a number of questions of concern not only to expert psychiatric witnesses but to medical experts in general (Rix 2015), particularly in regard to accreditation as indicated by the doctor's area of specialisation on the particular GMC specialist register; the relevance of previous higher specialty training to defining expertise; and the position of trainees who might be required to prepare expert reports, including as part of their higher specialty training.

Following the judgment of the Supreme Court in Kennedy v Cordia (Services) LLP [2016], which addressed the law concerning expert evidence, and the outcome of the appeal of the neuropathologist Dr Waney Squier, who was also found by the Medical Practitioners Tribunal (MPT) $)^{\mathrm{b}}$ to have acted outside her area of expertise (Squier $V$ General Medical Council [2016]), it is timely to set out the law concerning what amounts to expertise, in the context of expert medical evidence, and to provide accurate and up-to-date advice to psychiatrists, and indeed to all doctors, who are motivated, or obliged, to provide expert assistance in the administration of justice. This should be reassuring for those who have been deterred or worried by the Pool judgment.

In this first article we initially set out the law on expert evidence, then revisit Dr Pool's case, consider the case of Dr Squier in light of this exposition, and finally set out the implications of these cases. In our second article (Rix 2017) we suggest some good practice guidelines for doctors who offer themselves, or are called upon, to act as expert witnesses.
Keith Rix is an honorary consultant forensic psychiatrist, Norfolk and Suffolk NHS Foundation Trust, and Visiting Professor of Medical Jurisprudence, University of Chester, where he is involved with its MSc in Medicolegal Practice. He is an elected Honorary Fellow of the Faculty of Forensic and Legal Medicine of the Royal College of Physicians. Anthony Haycroft is a barrister-at-law with over 30 years' experience at the bar. He practises from Serjeants Inn Chambers. He concentrates on defending doctors and dentists, and examines and cross-examines experts of all disciplines on a weekly basis. Nigel Eastman is Emeritus Professor of Law and Ethics in Psychiatry and an honorary consultant forensic psychiatrist, St George's University of London, being dually qualified in medicine and law. Correspondence Professor Keith J. B. Rix, The Fermoy Unit, Queen Elizabeth Hospital, Gayton Road, King's Lynn PE30 4ET, UK. Email: keith.rix@nsft.nhs.uk

\section{Copyright and usage}

(C) The Royal College of Psychiatrists 2017.

${ }^{\dagger}$ This is the first of two articles by Rix et al that consider the Pool judgment. The second, 'After Pool: good practice guidelines for expert psychiatric witnesses', will appear in the next issue. Ed.

a. Now known as the Health and Care Professions Council.

b. The Medical Practitioners Tribunal Service has now become the Medical Practitioners Tribunal. 


\section{The law on expert evidence}

\section{Arrow injuries and silted harbours}

At least since 1282, in which year the opinion of a highly regarded surgeon was sought to advise a coroner whether a man struck in the breast by an arrow would die (Sayles 1936), expert evidence has been accepted as potentially necessary to assist the administration of justice.

The admission of expert evidence is an exception to the general rule that a person's belief or opinion is inadmissible as evidence, and that witnesses should speak only of what occurred factually, either in their presence or within their hearing. However, as Mr Justice Saunders said in Buckley v Rice-Thomas (1554):

'If matters arise in our law which concern other sciences or faculties we commonly apply for the aid of that science or faculty which it concerns.'

This was confirmed in what has been regarded as 'the principal case on the admissibility of matter of opinion', Folkes $v$ Chadd (1782), a case that concerned the silting up of Wells Harbour on the north Norfolk coast (Rix 2006). In response to objection to the admission of the opinion of two engineers, both Fellows of the Royal Society, Lord Justice Mansfield declared: 'In matters of science no other witnesses can be called'.

Clearly therefore the foundations of the law of expert evidence are long established. But are those foundations as secure now as in previous eras in terms of what, in law, amounts to 'expertise'? In particular, does the judgment of Mr Justice Lewis in Pool suggest a weakening or crumbling of those foundations?

There is no better place to look for answers to these questions than the Supreme Court of the United Kingdom, because its decisions are binding on all lower courts, tribunals and similar quasijudicial bodies in the UK (or, in the case of the criminal courts in Scotland, at least persuasive if not determinativec ${ }^{c}$. Kennedy is one, but the most important, of a number of recent cases in which the Supreme Court, or the Privy Council ${ }^{\mathrm{d}}$ on which the Supreme Court judges sit, has ruled on the law of expert evidence.

\section{Slipping up to the Supreme Court}

On 18 December 2010, Tracey Kennedy, a home carer, was visiting an elderly woman. She was employed by Cordia, which was owned by Glasgow City Council. She slipped and fell in the fresh snow that was overlying ice and injured her wrist. When she brought a claim for damages for personal injury before the Outer House of Scotland's Court of Session (Kennedy v Cordia (Services) LLP [2013]), evidence was called on her behalf from a consulting engineer, the Lord Ordinary who heard the case having repelled an objection that the engineer did not have any relevant special skill, experience or learning. The case was decided in Miss Kennedy's favour, and the defendant then appealed to an Extra Division of the Inner House of the Court of Session, the appeal being upheld unanimously by the three judges (Kennedy $v$ Cordia (Services) LLP [2014]). Miss Kennedy then appealed that decision to the Supreme Court.

Challenges to the admission of the engineer's factual evidence concerning how anti-slip attachments to footwear reduce the risk of slipping, and to his experience in carrying out, and advising his clients on, risk assessments, led the Supreme Court to address expert evidence more generally, in order to provide context for its conclusions. As it was a Scottish case, the Court referred to 'skilled evidence', as expert evidence is known in Scotland. It identified four matters that fell to be addressed (Box 1). We consider the first of these in some detail below.

\section{Admissibility of expert evidence}

\section{Fact or opinion?}

'Expert witnesses', or 'skilled witnesses', may give evidence as to both fact and opinion; and Lord Reed and Lord Hodge, giving the judgment of the Court in Kennedy, gave examples of both from Miss Kennedy's case. Hence, it was a matter of expert opinion whether she would have been less likely to fall if she had been wearing anti-slip attachments on her footwear; the slope of the pavement on which she lost her footing was a further example of a matter open to expert evidence, in terms of 'evidence of what he or she has observed if it is relevant to a fact in issue'. They also gave the example of a skilled witness giving evidence based on his or her knowledge and experience of a subject matter, drawing on the work of others, such as the findings of published research or the

BOX 1 The four matters in the use of expert evidence addressed in Kennedy

- The admissibility of expert evidence

- The responsibility of a party's legal team to make sure that the expert keeps to their role of giving the court useful information

- The court's policing of the performance of the expert's duties

- The cost of litigation (Kennedy v Cordia (Services) LLP[2016]) 
pooled knowledge of a team of people with whom he or she works'.

Lord Reed and Lord Hodge went on to use another example from a recent Privy Council case (Myers, Brangman and Cox v The Queen [2015]). In this case the Judicial Committee of the Privy Council approved the use of police officers who had special training and considerable experience of the practices of criminal gangs, to give evidence on the culture of gangs, their places of association and the signs that gang members used to associate themselves with particular gangs. Lord Reed and Lord Hodge said that, in giving such factual evidence, a skilled witness can draw on the general body of knowledge and understanding in which they are skilled, including the work and literature of others. However, they drew attention to the cautionary note sounded by Lord Hughes in Myers, that 'care must be taken that simple, and not necessarily balanced anecdotal evidence is not permitted to assume the robe of expertise'. To avoid this, they said that the skilled witness must set out their qualifications, by way of training and experience, to give expert evidence; and also say from where they had obtained information, if it was not based on their own observations and experience.

Within psychiatry, an example of an expert giving factual evidence would be a psychiatrist testifying that the defendant they examined in a criminal case had, at the time, been experiencing auditory hallucinations; the same psychiatrist offering the diagnosis of schizophrenia would amount to expert opinion evidence (although in psychiatry the distinction between fact and opinion is sometimes more open to question than in some branches of physical medicine, in that the psychiatrist cannot 'observe' the person's hallucinations, but only 'infer' them to have been present from the person's statements and observed behaviour). When that psychiatrist bases their reasoning on the work of others, in the form of published research concerning the differences between auditory hallucinations in schizophrenia and in bipolar disorder, they are giving expert factual evidence.

\section{Considerations governing the admissibility of expert or skilled evidence}

Citing and adopting the judgment in a South Australian case where Chief Justice King gave relevant guidance on the admissibility of expert opinion evidence ( $R$ v Bonython (1984)) (Box 2), Lord Reed and Lord Hodge, in Kennedy, identified four considerations which properly govern the admissibility of skilled evidence:
- whether the proposed skilled evidence will assist the court in its task

- whether the witness has the necessary knowledge and experience

- whether the witness is impartial in their presentation and assessment of the evidence; and

- whether there is a reliable body of knowledge or experience to underpin the expert's opinion.

They said that these apply to skilled evidence of fact as well as to opinion evidence, although when the first consideration is applied to opinion evidence the threshold is the necessity of such evidence.

\section{Assistance to the court}

Another important case is that of Naviera $S A \mathrm{~V}$ Prudential Assurance Co Ltd The Ikarian Reefer [1993]. This case, and its reasoning, was also adopted in Kennedy. In it Mr Justice Cresswell rehearsed the general rule that the expert should only give evidence in relation to matters within their expertise and on issues not within the ordinary experience of the jury. So that, if the jury is capable of forming an opinion without the assistance of an expert, because the matter is within their own experience or knowledge, then expert opinion is not 'necessary'. In deciding whether the proposed skilled evidence will assist the court, the authority is a case in which psychiatric evidence was ruled inadmissible on the ground that: 'Jurors do not need psychiatrists to tell them how ordinary folk

\section{BOX 2 The judgment of Chief Justice King in Bonython}

'Before admitting the opinion of a witness into evidence as expert testimony, the judge must consider and decide two questions. The first is whether the subject matter of the opinion falls within the class of subjects upon which expert testimony is permissible. This first question may be divided into two parts: (a) whether the subject matter of the opinion is such that a person without instruction or experience in the area of knowledge or human experience would be able to form a sound judgment on the matter without the assistance of witnesses possessing special knowledge or experience in the area, and (b) whether the subject matter of the opinion forms part of a body of knowledge or experience which is sufficiently organized or recognized to be accepted as a reliable body of knowledge or experience, a special acquaintance with which by the witness would render his opinion of assistance to the court. The second question is whether the witness has acquired by study or experience sufficient knowledge of the subject to render his opinion of value in resolving the issues before the court.'

(RvBonython (1984)) 
who are not suffering from any mental illness are likely to react to the stresses and strains of life' ( $R$ v Turner [1975]). In this case, Lord Justice Lawton held that:

'An expert opinion is admissible to provide the court with scientific information which is likely to be outside of the experience of a judge or jury. If, on the proven facts, a judge or jury can form their own conclusions without help, then the opinion of an expert is unnecessary.'

As well as being 'necessary', the evidence must be 'relevant' to the issue at hand, the word having a strict legal meaning. It is not enough for the evidence to be closely connected to the matter in hand. 'Relevance' is best understood as deriving from the 16th-century Scots legal term which means 'legally pertinent'. It has to be logically probative, or dis-probative, of some matter which requires proof; that is, it is evidence which makes the matter which requires proof more or less probable $\left(D P P_{V}\right.$ Kilbourne [1973]). If the evidence leaves the court no more certain as to the probability or improbability of the matter it is irrelevant and should not be admitted ( $L N_{v}$ Surrey NHS Primary Care Trust [2011]).

Finally, in order to assist the court, the evidence has to be 'reasoned', as held in the South African case of Coopers (South Africa) (Pty) Ltd v Deutsche Gesellschaft für Schädlingsbekämpfung $m b H(1976)$ :

'Proper evaluation of the opinion can only be undertaken if the process of reasoning which led to the conclusion, including the premises from which the reasoning proceeds, are disclosed by the expert.'

Lord Reed and Lord Hodge, in Kennedy, quoted approvingly Lord Prosser in Dingley v Chief Constable, Strathclyde Police (1998), who pithily stated: 'As with judicial or other opinions, what carries weight is the reasoning, not the conclusion'. Even more pithy is the observation of Mr Justice Jacob in Pearce v Ove Arup Partnership Ltd (2002): 'If the reasons stand up, the opinion does. If not, not'.

Expert assistance should, however, stop short of supplanting the court as decision maker on matters that are central to the case and to deciding 'the ultimate issue' before the court. The underlying rationale for the ultimate issue rule is as stated above, in Ikarian Reefer, that it is a matter for the judge or jury's own view.

However, this rule has become weakened in recent years, in that the Civil Evidence Act 1972 made expert opinion on the ultimate issue potentially admissible in civil cases; and in criminal cases abolition of the rule was recommended by the Criminal Law Revision Committee (1972) in its Eleventh Report, although the recommendation has never been put into effect.
Perhaps inevitably, given the ever-increasing complexity of some fields of expert evidence, there has been some softening of limitation of the issues on which expert opinion is admissible to those not amounting to the ultimate issue. For example, it is common for expert accountants to be allowed to state that there can be no rational and honest explanation for particular transactions, such that fraud (the ultimate issue) is inferred. Indeed, in the Ikarian Reefer case, Lord Taylor stated, as an aside, that:

\begin{abstract}
'the rationale behind the supposed prohibition is that the expert should not usurp the functions of the jury. But since counsel can bring the witness so close to opining on the ultimate issue that the inference as to his view is obvious, the rule can only be a matter of form rather than substance.'
\end{abstract}

Furthermore, one leading text on criminal law, Blackstone's, states:

'In practice the rule is largely ignored, or treated as being of only semantic effect, so that an expert is allowed to express an opinion on an ultimate issue, provided that the actual words he employs are not noticeably the same as those which will be used when the issue falls to be considered by the court' (Ormerod 2017: 2608-2609).

Another leading text on criminal law also suggests that the rule is effectively dead. Hence, Archbold, referring to $R$ v Fitzpatrick, states:

'An expert is now permitted to give his opinion on what has been called "the ultimate issue", but the judge should make it clear to the jury that they are not bound by the expert's opinion, and that the issue is for them to decide [...]; but a failure slavishly to follow this formula does not automatically render a conviction unsafe.' (Richardson 2016: para. 10.51).

However, where the ultimate issue can be avoided the court will endeavour to ensure this occurs. Lord Reed and Lord Hodge, again in Kennedy, referred to the recent case of Pora $v$ The Queen [2015], in which the Judicial Committee of the Privy Council ruled inadmissible the evidence of a forensic psychologist, on the basis that, in trenchantly asserting that the appellant's confessions were unreliable, he was supplanting the court's role. The court observed that the expert:

'could have expressed an opinion as to how the difficulties that Pora faced might have led him to make false confessions. This would have allowed the fact finder to make its own determination as to whether the admissions could be relied upon as a basis for a finding of guilt, unencumbered by a forthright assertion from the expert that the confessions were unreliable.'

By contrast, the evidence of another forensic psychologist that Pora's foetal alcohol spectrum disorder provided 'a possible explanation for his having admitted to something that he did not 
do' was accepted as evidence which was relevant to and, at least potentially, extremely helpful in determining whether Pora's confessions could be relied upon.

\section{The witness's necessary knowledge and experience}

There is no statutory definition of who is an expert under English law, but some helpful pointers are set out in Box 3.

Lord Reed and Lord Hodge (in Kennedy) summarised this position, relying on Myers (above):

'The skilled witness must demonstrate to the court that he or she has relevant knowledge and experience to give either factual evidence, which is not based exclusively on personal observation or sensation, or opinion evidence. Where the skilled witness establishes such knowledge and experience, he or she can draw on the general body of knowledge and understanding of the relevant expertise.'

One of the earliest cases in the line of jurisprudence of which this represents the settled position is that of a solicitor who was allowed to give expert handwriting evidence, on the basis of expertise acquired in the course of studying church registers as an amateur genealogist ( $R v$ Silverlock (1894)).

Box 4 gives further examples of the admission of non-professional/non-qualification expertise, and Box 5 gives examples of cases where professional qualifications were insufficient.

\section{Impartiality}

In setting out the requirement of impartiality on the part of the expert, Lord Reed and Lord Hodge pointed out that the Scottish courts have

\section{B0X 3 Who is an expert?}

Some helpful pointers to the definition of who is an expert:

- an expert needs expertise derived from 'knowledge or experience' - Section 4 of the Civil Evidence Act 1972

- 'a person who has specialized knowledge based on the person's training, study or experience' - Section 79 of the Evidence Act 1995 (New South Wales)

- 'a witness qualified as an expert by knowledge, skill, experience, training or education' - Rule 702 of the US Federal Rules of Evidence

- 'a person whose evidence is intended to be tendered before a court and who has relevant skill or knowledge achieved through research, experience or professional application within a specific field sufficient to entitle them to give evidence of their opinion and upon which the court may require independent, impartial assistance' - Crown Prosecution Service (2006).
BOX 4 Other examples of non-professional/ non-qualification expertise

A doctor opining on alcohol elimination rates based on analysts' tables $-R v$ Somers [1963]

A biologist who was a forensic DNA analyst giving statistical evaluation of DNA evidence without statistical qualifications - R v Fisher (2003)

A stenographer making a transcript of a police-obtained tape recording simply by listening to it without any qualifications in interpreting tapes - Hopes \& Lavery $v$ HM Advocate (1960)

A police officer experienced in investigating traffic collisions giving reconstruction evidence $-R v$ Oakley [1979]

A police officer giving evidence of what specific dose of a drug an addict would normally consume - White $v$ HM Advocate (1986)

A drug addict identifying a particular substance as being the drug they are addicted to $-R v$ Chatwood [1980]

adopted the guidance of Mr Justice Cresswell, as set out in the Ikarian Reefer judgment, which includes the duty and responsibility of the expert to present to the court expert evidence that is, and can be seen to be, the independent product of the expert, uninfluenced as to form and content by the exigencies of the litigation; and to provide assistance by way of objective, unbiased opinion on matters within their expertise.

\section{Reliable body of knowledge or experience}

The requirement that there should be a reliable body of knowledge or experience underpinning the expert's evidence is recognised as being easily satisfied where the subject matter of the proposed expert evidence is within a recognised scientific discipline. This ought to be so for expert psychiatric witnesses insofar as psychiatry involves a reliable body of knowledge and experience. However, it might not be true of the whole field of psychiatry.

BOX 5 Case examples of professional qualifications being insufficient

An emergency physician deemed inappropriate to testify to the qualities required of an emergency physician Seyfert v Burnaby Hospital Society (1986)

A doctor competent to testify to the medical examination carried out, but not to the theory of the scientific tests used - Gaudiuso v Walker (1989)

Doctors with and without sufficient expertise regarding whether wounds were self-inflicted $-R v$ Anderson [2000] 
An exceptional example is the area of multiple personality or dissociative identity disorder, in relation to which Piper \& Merskey (2004) have cogently argued that it is impossible to make a diagnosis reliably, and so have suggested that the US and Canadian courts cannot responsibly accept testimony in favour of dissociative identity disorder. Somewhat similarly, in $R v$ Gilfoyle [2001], evidence on 'psychological autopsy' was ruled inadmissible partly because there were no criteria by which the court could test the quality of the opinions expressed by the expert and partly because there was no substantial body of academic writing approving his methodology.

\section{Admissibility or weight?}

In the courts of first instance there are many examples of experts being found by the court to be giving evidence 'outside their field of expertise' or as 'not having sufficient expertise'; the former is potentially the focus of GMC sanctioning, the latter is not.

As examples of the latter, in $C$ v Dixon [2009] and Marchent $v$ Allied Domecq [2003], cases of brain injury following a road traffic accident and assault respectively, although the judges preferred the opinions of the neuropsychiatrists to those of the general psychiatrists, there was no assertion, or finding, that the general psychiatrists had strayed outside their expertise. In these and other cases, such as $R{ }_{V}$ Clarke and Morabir [2013], wherein the evidence of a pathologist in a murder case was excluded on the grounds that he was not on the register of Home Office Pathologists and did not have a higher relevant qualification such as the Diploma in Medical Jurisprudence, there seems to have been no criticism per se of the experts; and certainly no indication that, as with Dr Pool, they would be referred to the GMC. Indeed, in one such case (Dixon v Were [2004]), rather than being a potential professional regulation matter, the court decided that it was merely a matter of weight:

'[A]s neuropsychiatry deals with problems arising or appearing to arise after brain damage, whereas general psychiatry is principally concerned with illness, [the neuropsychiatrist's] evidence is entitled to particular weight.'

The case of Huntley $v$ Simmons [2010] is of particular interest. Here it was argued that, since the issue was the community treatment and prognosis of someone with brain damage, the principally relevant specialist expertise in the case was not neuropsychiatric or neurological but neuropsychological. However, the judge did not agree. Although he acknowledged that the neuropsychological opinions were of great importance, he was not persuaded that the issue in question was one on which a neurologist or neuropsychiatrist was unable to express a valid opinion, adding:

'Clinicians do not operate in impermeable boxes. Although $\mathrm{Dr}[\mathrm{X}]$ is a neuropsychiatrist by speciality, his particular clinical expertise is in the care and treatment in the community of patients with brain damage; and he told me that the nature of his practice meant that he had very considerable experience of the kinds of regime which he believed should have been implemented in the present case but had not been.'

These cases are to be distinguished from cases such as those of Pool and Squier since, in them, the experts passed the test of admissibility; and no question of the competence of the expert had arisen in the course of their evidence. It is, however, open to a court that has found an expert's evidence admissible then to decide, in the course of their evidence, that they are not competent to give an opinion on a particular issue, and so to remove their expert status mid-trial (as happened in $R \mathrm{v}$ Skingley \& Barratt (1999)). Weight is a separate matter to be considered once the evidence is given, when competence is fully considered in the light of the evidence. The degree of expertise then revealed is relevant to weight.

One could envisage some cases wherein the court might regard an expert as operating 'so far outside his field of expertise' as to end up in a regulatory arena. However, it is only if a complaint is made, for example by a litigant or the trial judge, that this will occur. Further, a regulatory case requires 'misconduct'; that is, a witness falling so far below an acceptable standard as to be 'serious'. Mr Justice Collins, in Nandi v General Medical Council [2004], observed that 'seriousness' in other contexts has been referred to as 'conduct which would be regarded as deplorable by fellow practitioners'. Of course, this would also mean the relevant expert strayed so far from their field of expertise that their opinion would be inadmissible.

\section{So who is an expert and what is the test?}

It follows from this exposition of the law that a specialist in a given field may be an expert; but also that someone who is not a specialist may be regarded as an expert nonetheless. So the matter of being an 'expert' is not, and should not be, restrictive.

Although the GMC maintains a specialist register under section 34D of the Medical Act 1983, and identifies doctors' areas of specialisation according to the provisions of Schedule 2 of the European Specialist Medical Qualifications Order 1995, it follows from the law that we have 
rehearsed above that a doctor does not need to be GMC registered in the relevant field in order to give an expert opinion. Further, inclusion on the specialist register as a specialist in a particular area $\mathrm{X}$ does not in itself prove that someone is an expert in specialist area X. Specialist registration is neither necessary nor sufficient to 'prove' expertise. Specialist registration, or its lack, would be too restrictive as a basis for determining expertise; and, clearly, specialist registration is established for purposes unrelated to the law of expert evidence. Rather, specialist registration (or its lack) may merely amount to one piece of evidence pointing to expertise (or its lack).

Hence, what is required to demonstrate expertise is that the doctor has sufficient knowledge and/ or experience in a field in order to be an expert therein; this is demonstrated by showing:

- possession of knowledge of the field of expertise, and

- an ability to use that knowledge by virtue of training and/or experience in that field.

\section{Pool revisited and Squier addressed}

\section{Pool}

In rejecting Dr Pool's appeal against the finding of the MPTS that his fitness to practise was impaired, Mr Justice Lewis held that the FPP was entitled to find as a matter of fact that he lacked the requisite expertise; and that by acting outside his field of expertise his fitness to practise was demonstrated to be impaired. Furthermore, of significance in relation to consideration of 'reasons' (above), $\mathrm{Mr}$ Justice Lewis also found that Dr Pool had not provided adequate reasoning for his opinions as to the degree of impairment of the practitioner's fitness to practise, or how long such impairment was likely to last. However, the case decides no new point of law. It is a decision on its facts (as all cases are regarding whether someone is an expert). Mr Justice Lewis did not cite a single case on expert evidence, since he considered the law to be clear and so merely applied it.

Medical concern over the case arose from the evidence of a psychiatrist, Dr Martin Baggaley, concerning 'medical expertise'. He was called by the GMC as an expert on expert medical evidence. However, Dr Baggaley's view of 'who is an expert' was at profound variance with the jurisprudence described in detail above, as summarised in Kennedy; and given the restrictive and essentially 'status'-based criteria he proposed, there was concern that the Court may have accepted the proposed criteria, which, if followed in other cases, would result in major and highly problematic
B0X 6 Dr Baggaley's 'tests' of expertise

1 Being on the specialist register in the appropriate area (i.e. general psychiatry)

2 Having Membership or Fellowship of the Royal College of Psychiatrists

3 Having undergone higher professional training

4 Having held a substantive NHS consultant post/ worked as a consultant in general adult psychiatry (for 20 years)

5 Having publications in the form of articles in peerreviewed journals and chapters

6 Having experience of working in the relevant setting ('the setting test')

7 Standing above one's peers in some respects/being above the line in terms of the hierarchy of expertise/ there being something about the psychiatrist's training and experience that sets them apart as an expert ('the peer/hierarchy test')

8 Not being a trainee psychiatrist unless very expert in a particular area

(Based on Rix (2015): Box 5)

implications for expert witness practice. As we shall see, the Court did not, in fact, accept Dr Baggaley's initial view and correctly applied the law. However, a hare was set running which caused alarm.

Dr Baggaley gave evidence that, in order to be an expert, a doctor had to be on the GMC specialist register in the relevant field, to have undergone higher training, and to be a consultant of 20 years' experience (Rix 2015). What may be regarded as 'Dr Baggaley's tests' of expertise are set out in Box 6.

Logically, application of these criteria would mean that, irrespective of experience, (a) a doctor can only be an expert if they have the appropriate qualifications; and (b) a doctor can be an expert on an issue by way of being in the appropriate category on the register. As will be clear from all of the foregoing, that view is simply legally wrong in both respects. Dr Baggaley's tests seem to express a medical view rather than accept the proper law, and are thereby too restrictive. The legal test is expressed in terms of a combination of training and experience. Indeed, Dr Baggaley's evidence as a whole, when tested, contradicted the initial view he expressed in terms of his restrictive criteria. Thus, in cross-examination, he accepted the definition of an expert in Phipson on Evidence:

'Though the expert must be skilled by special study or experience, the fact that he has not acquired his 
knowledge professionally goes merely to weight and not admissibility [...]. Equally, one can acquire expert knowledge in a particular sphere through repeated contact with it in the course of one's work, notwithstanding that the expertise is derived from experience and not formal training' (Malek 2013: p. 1189).

It was argued for Dr Pool that a person could acquire expert knowledge either from formal training or from experience gained in the course of work. That is correct, and Dr Baggaley ultimately accepted it (contrary to his main point about the specialist register). Mr Justice Lewis also accepted it, and found that the FPP had accepted it, in that it had not adopted Dr Baggaley's initial view of expertise. Both the FPP and Mr Justice Lewis therefore applied the correct law. Furthermore, as the FPP had found, clinical experience and knowledge are necessary but not sufficient to establish expertise:

'The panel considers that to put oneself forward as an expert witness requires more than clinical experience and knowledge. It also requires the ability to produce an adequate report and to give oral evidence in an authoritative and convincing manner' (MPTS (2014), unreported).

Mr Justice Lewis stated:

'the Panel was well aware and accepted that a person might be equipped to act as an expert either by reason of training or by reason of day to day experience. That is why the Panel considered the experience of the Appellant and considered whether that experience was such that he could properly put himself forward as an expert on the basis of such experience' (my italics) (Pool v General Medical Council [2014]).

Having considered that Dr Pool had insufficient qualifications, the main issue in the case was whether, as a matter of fact, his experience was sufficient to make him an expert in the relevant field. The FPP, Dr Baggaley and Mr Justice Lewis considered that, as a matter of fact, he did not have sufficient experience to make up for the insufficiency of his qualifications.

However, the case may be misunderstood because, on a practical level and as part of applying the correct legal test on expertise, the FPP used Dr Baggaley's evidence as a guide in deciding whether Dr Pool had sufficient experience, given that his qualifications alone were insufficient; but as a guide, and only as part of the factual matrix. Mr Justice Lewis similarly accepted Dr Baggaley's evidence as part of the facts that he used to analyse Dr Pool's 'experience' and to determine whether the FPP could justify its decision. Hence, both fact finders used the totality of Dr Baggaley's evidence on the issue, rather than applying his 'tests' as if they were law.
The FPP relied on the facts that Dr Pool was not working as a consultant in general adult psychiatry; he had no experience of working in the relevant setting; and he did not stand above his peers in some respects, or above the line in terms of the hierarchy of expertise. Mr Justice Lewis relied on the fact that Dr Pool was not on the specialist register in the area of general psychiatry; he had not completed any higher professional training; he was not currently treating, and he had no recent experience at a consultant level of treating, general psychiatry patients in community settings; his experience was not focused on the occupational functioning of patients; and he had no direct experience of working with patients with personality disorders in the context of 'fitness to practise' proceedings. Hence, crucially it is necessary to appreciate that these facts were merely the factual background of Dr Pool's experience, albeit relevant facts, but not prerequisites in law for providing an expert opinion.

Dr Pool's case may be regarded as a hard case. However, on careful analysis it was not a case that addressed what weight to give to an admissible opinion. Rather, on the facts Dr Pool was found to be so far outside his field of expertise that his evidence was simply not admissible at all; and his purporting to be 'expert' amounted to 'misconduct'.

\section{Squier}

Dr Waney Squier is a consultant paediatric neuropathologist whose medicolegal practice covered babies who had died of non-accidental head injury (NAHI). Between 2007 and 2010 she gave expert evidence about six babies, of whom five had died soon after allegedly suffering NAHI. As a result of her evidence in these cases, the Policing Improvement Agency complained about her to the GMC, and in consequence she appeared before an FPP of the MPT. The FPP accepted that Dr Squier had acquired expertise by qualification, study and experience, including having acquired a working understanding, as had her colleagues in her own and other disciplines, of the specialties of biomechanics, paediatric neurosurgery, neuroradiology and ophthalmology/ophthalmic pathology. It also found, as she often said in evidence in the original cases, that she deferred to the views of colleagues who were expert in the relevant field. This reflects the law as set out above.

On 21 March 2016, having made a number of findings of fact, the FPP found that Dr Squier's fitness to practise was impaired. Dr Squier appealed and Mr Justice Mitting found that the determination of the MPT was in many significant respects flawed (Squier v General Medical Council [2016]). 
However, he did uphold a number of the MPT's findings (Box 7).

Mr Justice Mitting accepted what the FPP stated about why Dr Squier was an expert. He made no reference at all to the case of Dr Pool. What he did point out was guidance as to the limits of expertise and the duty of an expert to give a balanced view and not mislead the court (Box 8).

Applying the above guidance, Mr Justice Mitting agreed with the FPP that in various cases 'Dr. Squier was guilty of misstatement by omission'. Ultimately, again this case is one of fact and raises no new point of law. Interestingly, given the complexity of the case, Mr Justice Mitting suggested that it would have been preferable for the FPP to have been chaired by a lawyer with judicial experience.

Mr Justice Mitting went on to decide that Dr Squier's fitness to practise was impaired as a result of her serious professional misconduct in repeatedly breaching the obligations of an expert medical witness in a number of cases, and compounding this in two cases by the deliberate mis-citation of research papers. The sanction he imposed was that conditions should be applied to her registration so as to prevent her from providing medicolegal reports or giving evidence in any court in the UK for 3 years, save for the provision of reports to the coroner on what she might find as a result of her ordinary practice. He accepted that maintaining public confidence in the profession included maintaining the confidence of the judiciary as a section of the public; and he said that Dr Squier had 'unhappily undermined that confidence'.

\section{Implications for expert psychiatric witness}

\section{The significance of higher specialist training and specialist registration}

Having undergone higher specialist training in a particular psychiatric subspecialty, or being listed as having a special area of psychiatric expertise on the GMC's specialist register, may establish that a psychiatrist is qualified to practise in that specialist area. It does not follow that such qualification will be sufficient for their evidence to be admitted as expert evidence. Their higher training may have been so long ago, for example, that it is no longer sufficiently relevant. Hence, to be an expert it may not be sufficient to be recognised as a specialist in a particular area by the GMC.

The corollary of this is that a psychiatrist who has not undergone higher training in a particular psychiatric subspecialty may have acquired sufficient knowledge through other training, or sufficient experience through repeated contact in

\section{BOX 7 Some of the MPTS findings upheld by} Mr Justice Mitting in the Squier case

- Dr Squier expressed opinions outside her field of expertise

- She often cited a research paper, not for its conclusion which did not support her opinion, but for some nugget within it which might - this was misstatement by omission

- She failed to be objective and unbiased

- She failed to pay due regard to the views of other experts

- Her evidence was misleading, in some cases deliberately so, and irresponsible

(Squier v General Medical Council [2016])

the course of their work, so as to be recognised as competent to provide expert evidence.

\section{The significance of consultant status}

It is not necessary to be a consultant to be an expert witness, let alone one for 20 years as Dr Baggaley initially suggested was required. It is perfectly possible for a psychiatrist who is not a consultant, for example a specialty registrar or a staff grade psychiatrist, to be regarded as competent to provide expert evidence. It all depends on whether their individual qualifications, training

BOX 8 Mr Justice Mitting's summary of the law as to the limits of expertise and the expert's duty to give a balanced view, in Squier

'The duties of an expert when citing the work of others are not controversial. The nature of the duty can be discerned from the following statements of principle.

i) In Re: $A B$ (Child abuse: expert witness) [1995] 1FLR 181 Wall J observed that when there was a genuine disagreement on a scientific or medical issue or where it was necessary for one party to advance a particular hypothesis, an expert is under the following duty:

"...the expert who advances such a hypothesis owes a very heavy duty to explain to the court that what he is advancing is a hypothesis, that it is controversial (if it is) and to place before the court all the material which contradicts the hypothesis. Secondly, he must make all his material available to the other experts in the case."

ii) Paragraph 10 of the GMC Guidance on Acting as an Expert Witness issued in July 2008 (withdrawn 22 April 2013a):
"10. You must make sure that any report you write or evidence you give is accurate and is not misleading. This means that you must take reasonable steps to verify any information you provide, and you must not deliberately leave out relevant information."

iii) Guidance for the Instruction of Experts to Give Evidence in Civil Claims 2014.

"13. Experts should take into account all material facts before them.

Their report should set out those facts and literature or material on which they have relied informing their opinions."

iv) Criminal Procedure Rules 2015: "19.4 ... An expert's report must b) give details of any literature or other information which the expert has relied on in making the report."'

a. Author's note: this is now replaced by General Medical Council (2013)

(Squier v General Medical Council [2016]) 
MCO answers

1 a $\quad 2 d \quad 3$ e $\quad 4 c \quad 5 c$ and experience in combination are sufficient for them to be able properly to assist the court on the issue in question.

\section{The court, not the psychiatrist, decides on the psychiatrist's competence to provide expert evidence}

Whether or not a psychiatrist's evidence is admissible is a matter for the court to decide, having regard to the necessity for expert assistance, the relevance of the evidence, and the qualifications and experience of the psychiatrist. What is required of the psychiatrist is to set out their qualifications, training and experience, including the nature and setting of their everyday practice, in sufficient detail so as to enable the court to decide whether their evidence should be admitted (Rix 2015). In the criminal jurisdiction, it is an actual requirement, under the Criminal Procedure Rules (Ministry of Justice 2016: rule 19.2(3)(a)), for the expert 'to define [their] area or areas of expertise' in their report. But in order for the court, or initially the potential instructing solicitors, to have all necessary information as to the (potential) expert's qualifications, training and experience so as to make a decision on admissibility, this information should be provided at as early a stage as possible. It should enable the court to be clear as to what is the expert's core expertise and what the related disciplines or specialties are of which the expert has a working understanding or knowledge.

Expert evidence cannot be admitted without the permission of the court. Further, if necessary, at a pretrial hearing, the court may make binding rulings about the admissibility of evidence, including expert evidence. This is what happened in Dr Pool's case when he was to give evidence in the HPC proceedings: the HPC held a preliminary hearing in order to decide whether his evidence should be admitted. However, he had by this time consulted with the practitioner and his report on her had been disclosed to the HPC.

\section{Summary}

The criteria for medical expertise within legal process are determined not within a medical paradigm but legally; and there is a clear distinction between 'admissibility' and 'weight'. Specifically, it is a question of fact in each individual case whether someone is a medical 'expert' in a field, based on consideration of the combination of their qualifications, training and experience. As such, the concept is a flexible one, and not a rigid one based on 'status' criteria. The alarm that spread across the psychiatric establishment consequent on confusion on the part of non-lawyers as to whether the court had accepted Dr Baggaley's proposed tests was understandable, unfortunate and ultimately unnecessary. It perhaps also emphasises the importance of doctors, including doctors called as experts in fitness to practise hearings, making clear when they are giving an opinion within a medical paradigm and when they are applying medical evidence to legal criteria.

A useful check on expertise is whether the person can reason their opinion drawing on their qualifications, training and experience, including any research or publications of which they are aware and which they can explain. Hence, someone with appropriate qualifications gained many years ago may, for example, no longer be an 'expert', as they cannot give a relevant current opinion. Someone with more basic qualifications or training may be an 'expert' if their experience is sufficient in the view of the court or tribunal.

Ultimately, it is incumbent on any doctor approached to be an expert to determine for themselves whether they are properly able to be so, in terms of the legal criteria. That is, whether the case is within their 'field(s) of expertise'. Thus, before accepting instructions they should consider whether their particular qualifications, training and experience in combination determine that they are an appropriate expert for the specific case.

\section{References}

Criminal Law Revision Committee (1972) Eleventh Report (Cmnd 4991). HMSO.

Crown Prosecution Service (2006) Disclosure Manual - Annex K. Disclosure: Experts' Evidence and Unused Material - Guidance Booklet for Experts. CPS.

General Medical Council (2013) Acting as a Witness in Legal Proceedings. GMC (http://www.gmc-uk.org/static/documents/content/Acting_as_a_ witness_in_legal_proceedings.pdf).

Malek HM (ed) (2013) Phipson on Evidence (18th edn). Sweet \& Maxwell.

Ministry of Justice (2016) The Criminal Procedure Rules: The Criminal Practice Directions. October 2015 Edition. Ministry of Justice (https:// www.justice.gov.uk/courts/procedure-rules/criminal/docs/2015/ criminal-procedure-rules-practice-directions-2015.pdf).

Ormerod D, Perry D (2017) Blackstone's Criminal Practice. Oxford University Press.

Piper A, Merskey H (2004) The persistence of folly: critical examination of dissociative identity disorder. Part II. The defence and decline of multiple personality or dissociative identity disorder. Canadian Journal of Psychiatry, 49: 678-83.

Richardson PJ (2016) Archbold Criminal Pleading, Evidence and Practice. Sweet \& Maxwell.

Rix KJB (2006) England's first expert witness? The Expert and Dispute Resolver, 11(2): 15-18.

Rix KJB (2015) When is an expert not an expert? Question time for expert psychiatric witnesses. BJPsych Advances, 21: 295-303.

Rix K, Eastman N, Haycroft A (2017) After Pool: good practice guidelines for expert psychiatric witnesses. BJPsych Advances, in press.

Sayles GO (1936) Select Cases in the Court of King's Bench under Edward I. Bernard Quaritsch. 


\section{Cases}

Buckley v Rice-Thomas (1554) 1 Plowd 118.

C v Dixon [2009] EWHC 708 (0B).

Coopers (South Africa) (Pty) Ltd $v$ Deutsche Gesellschaft für Schädlingsbekämpfung mbH(1976) (3) SA 352.

Dingley v Chief Constable, Strathclyde Police (1998) SC 548.

Dixon v Were [2004] EWHC 2273 (OB).

DPP v Kilbourne [1973] AC 729.

Folkes v Chadd (1782) 3 Doug KB, 591.

Gaudiuso v Walker (1989) 56 DLR (4th) 355.

Hopes \& Lavery v HM Advocate (1960) JC 104

Huntley $v$ Simmons [2010] EWCA Civ 54.

Kennedy v Cordia (Services) LLP [2013] CSOH 130.

Kennedy v Cordia (Services) LLP [2014] CSIH 76.

Kennedy v Cordia (Services) LLP [2016] UKSC 6.

LN v Surrey NHS Primary Care Trust [2011] UKUT 76 (AAC) LN v Surrey NHS Primary Care Trust [2011] UKUT 76 (AAC).

Marchent v Allied Domecq [2003] EWHC 82 (QB).

Myers, Brangman and Cox v The Queen [2015] UKPC 40.

Nandi v General Medical Council [2004] EWHC 2317 (Admin).
Naviera SA v Prudential Assurance Co Ltd The Ikarian Reefer [1993]

2 Lloyd's Rep 68.

Pearce v Ove Arup Partnership Ltd(2002) 25(2) IPD 25011.

Pool v General Medical Council [2014] EWHC 3791 (Admin).

Pora $v$ The Queen [2015] UKPC 9

$R \vee$ Anderson [2000] VSCA 16.

$R v$ Bonython (1984) 38 SASR 45.

$R v$ Chatwood [1980] 1 All ER 467.

$R$ v Clarke and Morabir [2013] EWCA Crim 162.

$R$ v Fitzpatrick [1999] Crim LR 832, CA.

$R v$ Fisher (2003) 179 CCC3d 138.

$R$ v Gilfoyle [2001] 2 Cr App R 57.

$R v$ Oakley [1979] RTR 417

$R$ v Silverlock (1894) 2 OB 766

$R$ v Skingley \& Barratt (1999) Unreported CA 27 Dec.

$R v$ Somers [1963] 3 All ER 808.

$R$ v Turner [1975] 1 All ER 70.

Seyfert v Burnaby Hospital Society (1986) 27 DLR (4th) 96.

Squier v General Medical Council [2016] EWHC 2739 (Admin).

White v HM Advocate (1986) SCCR 224

\section{MCOs}

Select the single best option for each question stem

\section{Expert evidence:}

$a$ is admissible if its subject matter is outwith the knowledge and experience of the judge or jury

b is admissible provided that it does not address the ultimate issue

c must be limited to opinion and not facts

d complies with the rule that a witness can only give evidence of what actually occurred either in their presence or within their hearing

e was first admitted in the landmark Wells Harbour case of Folkes v Chadd.

2 For the purposes of the administration of justice, expertise:

a must be based on professional experience

b must be based on the possession of appropriate qualifications

c must be evidenced by peer-reviewed publications in the relevant field d can be acquired by repeated contact in the course of one's work

e is evidenced by specialist registration with the General Medical Council in the appropriate area.

3 The case of Kennedy $v$ Cordia:

a is a Scottish case that does not affect expert witness practice in England and Wales

b makes an important distinction between a skilled witness and an expert witness

c was appealed to the Supreme Court because there was disputed neuropathological evidence

$d$ involved a rejection of the law on expert evidence as it has been adopted in South Australia in $R v$ Bonython

e refers to the distinction between an expert's core area of expertise and their working knowledge of related disciplines.

4 The case of Dr Richard Pool:

a has led to the introduction of new tests that govern the admissibility of expert evidence b was decided by the application of Dr Baggaley's 'tests' of expertise

$c$ is a fact-specific case

d has provided reassurance to experts seeking to define the boundaries of their area of expertise

e was cited as authority for finding that Dr Waney Squier's fitness to practise was impaired.

5 In order to provide expert evidence, a psychiatrist:

a must have completed higher training in the appropriate specialty

b must have at least 20 years' experience as a consultant

c must have sufficient knowledge or experience

$\mathrm{d}$ must hold or have held a consultant appointment in the NHS

e must be a Member of the Royal College of Psychiatrists. 